\title{
Promotion of Child Mental Health among Primary School Teachers
} \author{
Pankaja TC $^{6}$ and Rajendra Badesgol ${ }^{7}$ \\ ${ }^{1}$ Susheelkumar V Ronad, Department of Psychiatric Nursing, Dimhans Dharwad, Karnataka, India \\ ${ }^{2}$ Chetan S Patali, Principal, Dhanush institute of Nursing Sciences Bagaklot \\ ${ }^{3}$ Shridhar H Gondbal, Staff Nurse, Indira Gandhi Children's Hospital, India \\ ${ }^{4}$ Kirankumar TC, Department of Management Studies, Karnataka Arts College, India \\ ${ }^{5}$ Mallikarjuna I Ronad, Civil Engineering Student, MSRUAS Bangalore, India \\ ${ }^{6}$ Pankaja TC, RL Law College, Davangere, India \\ ${ }^{7}$ Rajendra Badesgol, Department of Police, Belgaum, India
}

Susheelkumar V Ronad ${ }^{1 *}$, Chetan S Patali², Shridhar H Gondbal ${ }^{3}$, Kirankumar TC ${ }^{4}$, Mallikarjuna Ronad ${ }^{5}$,

Submission: May 07, 2018; Published: May 21, 2018

*Corresponding author: Susheelkumar V Ronad, Department of Psychiatric Nursing, Dharwad Institute of Mental Health and Neurosciences, India, Email: susheelronad@gmail.com

\section{Introduction}

The child is the most precious possession of mankind, most beloved and perfect in its innocence. The child represents a face of man which is always happy and always new. With every child we are born again and we play in the courtyard of the world in the bright sunshine of love and laughter [1]. Childhood is the period where every individual learns the basics of almost everything. Human beings have a keen sense to adapt to their surroundings and this is what child development encompasses. This period is not same for everyone but certain milestones have been formulated which can be used to measure the progress of the child's development. When a child reaches these milestones in the prescribed time period he is considered as a normal child. The normal childhood seems to be one in which parents do not emphasize the important qualities of life to their children. The children are never taught the importance of learning; asking questions; knowing right from wrong; respecting others and their possessions; sharing with others; and listening. Normal childhood is what the majority of the society perceives. Child development refers to the biological psychological and emotional changes that occur in human beings between birth and the end of adolescence then through adulthood, as the individual progresses from dependency to increasing autonomy. The Hindu Philosophy places teacher on a pedestal-even above God and just after the parents. Children spend most of their time in school with teachers who play an important role in moulding their future. A teacher is responsible for the integrated all round development of a child. Like a gardner, he provides all suitable conditions for their best growth [1]. Learning is a very complex brain function of understanding, recalling and utilization of this knowledge in the future. The capacity to learn varies from individual to individualeven among children of the same age and intellectual ability. Without proper knowledge and perception regarding their reality, all parents and teachers force the children to come out with first rank.

The term 'learning disability' came to use in the 1960's. Learning disorder is also termed as 'specific learning disorder' or 'specific academic skill disorder'. National Joint Committee on Learning Disorder defines learning disorder as "a heterogenous group of disorder manifested by significant difficulties in the acquisition and use of listening, speaking, reading, writing, reasoning or mathematical abilities" [2].

The fourth version of DSM (DSM-IV) of mental disorders refer these disabilities as learning disorder rather than academic skill disorder and mentioned under the section called 'disorders first diagnosed in infancy, childhood, or adolescence [3]. According to UNESCO (2005) records of European countries, the percentage of students learning in special schools ranges between 2.5 to 4.5 and $10-15 \%$ of the school age population is in special education needs, which include defects of speech, major behavioural problems and various forms of learning disabilities. $4.5 \%$ of students in schools had been identified as having learning disorders [4]. Identification of disorder prior to school age is difficult due to the instability of results obtained from formal testing procedures. Teachers are the first person to notice that the child is not learning as expected. Shaw and Mac (2005) stated that for students with a learning disorder, 'planning, monitoring, regulating and scheduling' are 
difficult. These students require continous help to adapt learning situations. Selvi (2004) in a analysis of challenging behaviours among people with learning disorder suggests that these children are a major challenge for teachers and members of caring families. The success of these children is determined by the response of the school personnel to the needs of these children [5]. Preschool children constitute about 5 percent of the total population and are vulnerable for various infections. In Raichur preschool children constitutes about $13 \%$ of the total population. Hence there should be a motto to guide each and every child to follow and practice cleanliness, as 'cleanliness is next to godliness'. As there is more prevalence of ignorance and illiteracy among the public, there is a great need to educate them, especially the children about good hygienic practices and to promote healthy life style [2]. The purpose of evidence based interventions in youth mental health prevention and promotion is to review the current scientific knowledge on mental health promotion interventions aimed at children and adolescents. Definitions of mental health, mental health prevention and mental health promotion are provided. The current state of knowledge in this area was assessed based on a specific method involving selection, a literature review and a classification of mental health promotion interventions identified using scientific databases. Seventeen interventions were identified as having an effect on youth mental health. Half of these interventions are aimed at the general population, while the other half target vulnerable individuals. The majority of the interventions are aimed at children aged 5 and over. Half of the interventions are multimodal, while unimodal interventions include programs aimed at promoting psychosocial competencies in children [1].

Challenges and ideas from a research program on high quality, evidence based practice in school mental health reviews the progression of a research program designed to develop, implement, and study the implementation of "achievable" evidence-based practices (EBPs) in schools. We review challenges encountered and ideas to overcome them to enhance this avenue of research. A number of challenges, many not reported in the literature, are reviewed, and ideas for overcoming them are presented. Given the reality that the majority of youth mental health services are delivered in schools and the potential of school mental health services to provide a continuum of mental health care from promotion to intervention, it is critical that the field consider and address the logistical and methodological challenges associated with implementing and studying EBP implementation by clinicians [2]. The European Union Dataprev project reviewed work on mental health in four areas, parenting, schools, the workplace and older people. The schools work package carried out a systematic review of reviews of work on mental health in schools from which it identified evidence-based interventions and programmes and extracted the general principles from evidencebased work. The effects associated with interventions were variable and their effectiveness could not always be relied on. The characteristics of more effective interventions included: teaching skills, focusing on positive mental health; balancing universal and targeted approaches; starting early with the youngest children and continuing with older ones; operating for a lengthy period of time and embedding work within a multi-modal/wholeschool approach which included such features as changes to the curriculum including teaching skills and linking with academic learning, improving school ethos, teacher education, liaison with parents, parenting education, community involvement and coordinated work with outside agencies. Interventions were only effective if they were completely and accurately implemented: this applied particularly to whole-school interventions which could be ineffective if not implemented with clarity, intensity and fidelity. The implications for policy and practice around mental health in schools are discussed, including the suggestion of some rebalancing of priorities and emphases [3].

\section{Need for the Study}

An integrative review of literature was undertaken to examine the impact of children's mental health on their school success. The literature confirmed a confluence of problems associated with school performance and child and adolescent mental health. Poor academic functioning and inconsistent school attendance were identified as early signs of emerging or existing mental health problems during childhood and adolescence. Among the goals of school nursing is to provide a process for identification and resolution of students' health needs as they affect educational achievement. Thus, it is within the scope of practice and goals of school nursing to also address children's mental health needs, as they affect school performance. This review of literature supports the conclusion that school nursing is well positioned to respond to the need for mental health promotion, illness prevention, and early intervention related to children's mental health [4]. Teacher is the role model and they understand the children's feelings and stress. It's important for the teacher to know the importance of child's mental health. Mental health is the capacity of the individuals and groups to interact with one another and the environment in ways that promote subjective well-being, optimal development and the use of cognitive, affective and relational abilities. If we educate teachers then they will be keen enough to provide basic environment and make suitable strategies for the promotion of child mental health. That's why I selected this topic. The World Health Organization (WHO) defines learning disabilities as: "a state of arrested or incomplete development of mind". Learning disability is a diagnosis, but it is not a disease, nor is it a physical or mental illness. Unlike the latter, so far as we know it is not treatable [5-18].

Learning disabilities, or learning disorders, are an umbrella term for a wide variety of learning problems. A learning disability is not a problem with intelligence or motivation. Kids with learning disabilities aren't lazy or dumb. In fact, most are just as smart as everyone else. Their brains are simply wired differently. This difference affects how they receive and process information. The most common types of learning disabilities involve problems with 
reading, writing, maths, reasoning, listening, and speaking [19]. In industrialized countries such as United States, a prevalence rate for childhood chronic illness and disabilities has been estimated at $10 \%$. According to Dr. Prasad M, (2000) prevalence rate of 20$33 \%$ of psychiatric disorders in school children has been reported in India. $7 \%$ of them are developmental disorders. Among them, learning disorder constitute 1 in 10 children. In India, ever7 section of the school is likely to have around $15-25 \%$ of students, who are not able to maintain a satisfactory scholastic performance in school [20]. A study was conducted in an urban area of Dharwad city (2008). Children studying in 6th standard from selected fourteen schools based on their previous academic performance of the class tests and the teacher's rating were selected as subjects for the study. The results of screening tests showed that in reading $93 \%$ of academically low children were found to be difficult and none of them were found to be normal. Where as in writing ability $58 \%$ were difficult, $24 \%$ were normal and $18 \%$ were found to be average [21]. In India, around $13-14 \%$ of all school children suffer from learning disorders. Unfortunately, most schools fail to lend a sympathetic ear to their problems. As a result, these children are branded as failures. Samir Parikh (2009) a Child Psychiatrist, opines that learning disorder is not a disease but it's a lifelong problem and presents challenges that need to be overcome every day. He argues that with proper diagnosis, appropriate education, hard work and support from family, friends, teachers and others, they can lead a successful and productive life [22-40].

According to National Centre for Learning Disability (2005), teachers are the essential link between children with learning disorders and the interventions that help them. Trained teachers that have positive attitude and practical knowledge concerning individual needs and problems can prevent and manage emotional and psychosocial problems of young children [41]. In a country like India where resources are very limited, better and efficient utilization of the available resource is the only solution for the problem. Realization of these reality paved the way for the 9th conference of Central Council of Health and Central Family Welfare Council in 1996 declare that 'the teachers should be trained for observing and screening students for defects and deviations from normal health to maintain effective surveillance and for providing supportive health education for the prevention of health problems by developing desirable health habits [42]. This awareness made the researcher to assess the knowledge of school teachers regarding the early detection and management of learning disabilities in children. The result of the study can encourage other researchers or educational department to include necessary curriculum in the teacher training programme [43-56].

\section{References}

1. Child, WIKIPEDIA, the free Encyclopedia.

2. Basavantappa BT (1998) Nursing Research New Delhi. JP Brothers, India.
3. Berninger VW, Raskind W, Richards T, Abbott R, Stock P (2008) A multidisciplinary approach to understanding developmental dyslexia within working-memory architecture: genotypes, phenotypes, brain, and instruction. Educational Psychology, University of Washington, Seattle, USA 33(6): 707-744.

4. Park K (2005) Text Book of Preventive and Social Medicine ( $18^{\text {th }}$ edn $)$, M/S Bannarasidas Bhanot Publishers Jablapur, Inida.

5. indg.gov.in/health/hygiene/personal-hygiene-1.

6. Bathing, WIKIPEDIA, the free Encyclopedia.

7. Toileting, WIKIPEDIA, the free Encyclopedia.

8. Wikipedia, Necator americanus and Ancylostoma duodenale, the free encyclopedia.

9. Mahajan VK (1995) Text Book of Preventive and Social Medicine. $\left(2^{\text {nd }}\right.$ edn), Jaypee Brothers Medical Publishers.

10. Denise F Polit (2004) Nursing Research Principles and Methods, Philadelphia, Lippincott. $\left(7^{\text {th }}\right.$ edn), Lippincott Williams \& Wilkins, Philadelphia.

11. Ramseier CA, Leiggener J, Lang NP, Bagramian RA (2007) Short term effects of hygiene education for preschool (Kindergarten) children. Oral Health Prev Dent 5(1): 19-24.

12. Kang BH, Park SN, Sohng KY, Moon JS (2008) Effect of tooth brushing education program on oral health of preschool children. J Korean Acad Nurs 38(6): 914-22

13. Mohana Kumari D (1999) A study to assess awareness of hygiene practices on children in Government Raj Bhavan School, Hyderabad, India.

14. Ilika AL (2002) Personal hygiene practice and school based health education of children in Anambra state. Nigeria. Niger Postgrad Medical Journal Medline 9(2): 79-82.

15. Biswas AB (1990) A study of the impact of health education to school children on their knowledge, attitude and practice in regard to personal hygiene. Indian Journal of Public Health. New Delhi, India 34(2): 87-92.

16. Taani DS, Muhsen K, Cohen D (2003) Caries free smile, oral health education. Rev Salud Publica.

17. Neeraja KP (2003) Textbook of Nursing Education. 1st edition. Jaypee Brothers Medical Publishers (P) Ltd New Delhi, India.

18. http://www.ctl.unl edu/tfi 14.html.

19. Neeraja KP (2010) Text Book of Nursing Education. (1 $1^{\text {st }}$ edn), Jaypee Brothers medical publishers Private limited, Inida, Pp: 294-295.

20. Llewellyn Claire (2007) Hygiene and Health. QEB Publishers, UK.

21. Gray Shirley Wimbish (2003) Personal Hygiene and Good Health. Child's World Publishers, UK.

22. Kidd EAM (2005) Essentials of Dental Caries. Oxford University Press, Oxford, Inida.

23. http://www.nifl.gov/facts/learning disabilities.html.

24. Sines D, Selvin E (2005) The role of community nurses for people with learning disabilities: working with people who challenge. International Journal of Nursing Studies 42: 415-427.

25. http://www.helpguide.org/mental/learning_disabilities.htm.

26. Shelton D (2000) Child Mental Health Policy of Peadiatric Nursing. (5 $5^{\text {th }}$ edn), jaypee publications .New Delhi.

27. http://www.learning disabilities India/edu.com.

28. http://www.ld.org.getreadytoread.org. 
29. Heneren R, Birrel R, Orby J (1996) Mental Health Programmes in schools. Journal of World Health 31(2).

30. Polit DF, Hungler BP (2004) Nursing Research: Generating and Assessing Evidence for Nursing Practice. 8th edition. LWW Publications. Philadelphia.

31. Mc Nulty MA (2009) Dyslexia and life course. Journal of learning disability july augest 36(4): 363-381.

32. Dellalolas G, Waiter L, Giannopulee I (2007) A longitudinal school study on behavior difficulties, attention difficulties and learning problems in children aged 3.5- 8 years. Arch pediatrics 14(3): 227-233.

33. Reynolds D, Nicholson RL (2007) Follow up of an exercise based treatment for children with reading difficulties. Dyslexia 13(2): 78-96.

34. Justice LM, Bowles RP (2009) school readiness among children with varying histories of learning difficulties. Developmental psychology 45(2): 460-476

35. Helland $\mathrm{T}$ (2008) Dichotic listening and school performance in dyslexia. Dyslexia 14(1): 42-53.

36. Pandit Ramjee Prasad (2008) Factors affecting learning disability in mathematics: a study of central region of Nepal.

37. Padmavathi D, Lalitha KA (2009) study on effectiveness of structured teaching programme for teacher trainees towards learning disabilities. Nightingale nursing times 5(6): 14-18

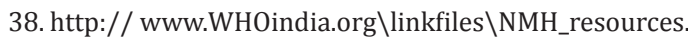

39. Javelin CMS, Roth JMD (2008) Medical practice in Edmond, Oklahoma, dedicated to helping families by evaluating children with developmental and behavioral issues. Indian journal of pediatrics 3(1): 56-59.

40. Usha P, Kuruvilla M (2002) Supporting system and certain bahaviors problems of preschool children in Malappuram District. Project Report, India.

41. Terri Kyle (2008) Essential of Pediatric Nursing. ( $1^{\text {st }}$ edn), Wolkers Kluwer Publishers Pvt Ltd New Delhi, India.

42. A guide to your personal growth.
43. DSM IVTM (2000) APA Diagnostic and statistical manual of Mental disorders. ( $4^{\text {th }}$ edn), Jaypee publications. New Delhi, India.

44. Rajamanickam M (2007) Text Book of Psychiatry. ( $1^{\text {st }}$ edn), Publishers GNOSIS, New Delhi, India.

45. Bear GG (2015) Best practices in school discipline. UCLA centre for Mental health in schools, Los Angeles, USA.

46. Stanhope, Lancaster (2006) Community health nursing. (4 $4^{\text {th }}$ edn), Mosby Publications, Missouri, USA, pp. 537.

47. (2010) Spanish: The Association Director of Communication; c20072010. Department of Health and Human Services.

48. Giallo R, Little E (2003) Classroom Behaviour Problems. Australian. Journal Of Educational and Developmental Psychology 3(2): 21-34.

49. World Health Organization (2001) The world Health Report mental health: New understanding. New scope, Geneva, Switzerland.

50. Tirkey L, Johan M (2007) Behavioural problems in school going children in India. Eastern J Psychiatry 10(1): 11-14.

51. Polit DF (2003) Nursing Research Principles and Methods. ( $3^{\text {rd }}$ edn), JB. Lippincott Company, Philadelphia, USA, pp. 32-35.

52. Gupta I (2001) Prevalence of behavioral problems in school going children. Ludhiana, India. Indian pediatric 68(4): 323.

53. Rahman A, Asal A, Moataz M, Fattah A (2004) Emotional and Behavioural problems among male Saudi school children and adolescents, Prevalence and Risk Factors. German Journal of Psychiatry, p. 64-71.

54. Hissein SA, Haidry SE (2009) Prevalence of emotional and behavioral problems among primary school children in Karahi, Pakistan-multi informant survey. Indian Pediatric J 76(6): 623-627.

55. Lloeje SO (2011) Rutter's behavior scale (B2) for children (Teacher's scale), validation and standardization for use on Nigerian children. East Afr Med 78(6): 308-311.

56. Holmberg, De geer L, Sward C (2004) Behavioural and Learning Problems In school Related to Cognitive Test Data. Acta Paediatrica 93: 976-981.

\section{Your next submission with Juniper Publishers} will reach you the below assets

- Quality Editorial service

- Swift Peer Review

- Reprints availability

- E-prints Service

- Manuscript Podcast for convenient understanding

- Global attainment for your research

- Manuscript accessibility in different formats

( Pdf, E-pub, Full Text, Audio)

- Unceasing customer service

Track the below URL for one-step submission https://juniperpublishers.com/online-submission.php 